Ritrýnd grein birt 23. nóvember 2020

\title{
Sýrlenskir nemendur í íslenskum grunnskólum: Upplifun nemenda, foreldra og kennara ${ }^{1}$
}

\author{
Hermína Gunnpórsdóttir, Kheirie El Hariri og Markus Meckl \\ Abstract \\ - Um höfundana \\ About the authors \\ Heimildir
}

Árið 2016 tók Ísland á móti hópi sýrlenskra kvótaflóttamanna í samstarfi við Flóttamannastofnun Sameinuðu pjóðanna. Í pessari eigindlegu rannsókn er upplifun hluta pessa hóps, kennara hans og foreldra, af grunnskólanámi á Íslandi könnuð. Til gagnaöflunar voru notuð hálfstöðluð viðtöl. Pátttakendur voru alls sautján; foreldrar og börn úr premur fjölskyldum og fimm kennarar, og voru tekin viðtöl einu sinni, vorið 2018. Einstaklingsviðtöl voru tekin við kennara og foreldra en hópviðtöl tekin við nemendur. Demagreining var notuð við að greina gögnin. Niðurstöður eru kynntar undir premur meginpemum: (1) Að skilja ný viðmið um nám og kennslu, (2) Hlutverk samskipta og ábyrgð, og (3) Er Ísland hluti af framtíðinni? Demun prjú eiga sér sameiginlegan práð sem ræddur verður sérstaklega en pað er menningarmunur sem birtist pó með ólíkum hætti í máli viðmælenda. Niðurstöður benda til pess að menningarleg gildi hafi haft áhrif á menntunarferlið sem varð til pess að samskipti heimilis og skóla urðu ómarkviss. Dað leiddi meðal annars til pess að foreldrar báru ekki fullt traust til íslenskra skóla barna sinna. Kennara virtist skorta viðeigandi stuðning og pjálfun til að takast á við aðstæður pessa tiltekna nemendahóps. Prátt fyrir petta sögðust nemendur sjálfir vera ánægðir með skólann sinn og eiga í góðu sambandi við kennara sína.

Efnisorð: Íslenskir grunnskólar, menntun, fjölmenning, flóttamenn

\section{Inngangur}

Árið 2016 tók Ísland, í samstarfi við Flóttamannastofnun Sameinuðu bjóđanna, á móti hópi sýrlenskra kvótaflóttamanna sem dvalið höfðu í flóttamannabúðum í Líbanon. Í hópnum voru fjölskyldur með börn á skólaaldri. Mikilvægur páttur í aðlögunarferli flóttafólks er menntun, en hún er lykilvettvangur fyrir íbúa móttökulandsins og komandi íbúa að læra hvorir um aðra (Hannah, 2007; Lerner, 2012). Dví er mikilvægt að menntastefna og starfshættir skóla taki mið af stöðu flóttafólks. Með pví að rannsaka upplifun nemenda, foreldra, kennara og peirra sem að námsferlinu koma má öðlast dýrmætar upplýsingar til að efla aðlögun og námsferli pessa hóps.

Dessari rannsókn er ætlað að stuðla að betri skilningi á reynslu sýrlenskra flóttabarna og foreldra peirra varðandi íslenska grunnskóla, sem og á reynslu kennara af samskiptum við pennan hóp. Fáar íslenskar rannsóknir hafa verið gerðar sem fjalla um sýrlensk börn í íslensku skólakerfi sem jafnframt eru flóttamenn en hér má pó til dæmis benda á rannsókn Hönnu Ragnarsdóttur og Susan Rafik Hama (2018), par sem sjónum var beint að fyrsta ári peirra á Íslandi. Dennan skort á rannsóknum má rekja til pess að aðeins eru prjú ár síðan fyrstu sýrlensku flóttamennirnir komu til landsins.

1 Rannsóknin var styrkt af Rannsóknamiðstöð Íslands (Rannís) og Byggðastofnun. 
Dessi rannsókn var framkvæmd með pátttöku fjölskyldna sem búsettar eru utan höfuðborgarsvæðisins, en par eru mjög fáir íbúar af arabískum uppruna. Tilgangur pessarar rannsóknar er að styrkja mótun og framkvæmd menntastefnu fyrir flóttafólk með pví að draga fram sjónarmið nemenda úr hópi pess, sem og foreldra peirra og kennara. Meginmarkmiðið er að fá innsýn í reynslu sýrlensku nemendanna, foreldra peirra og kennara í grunnskóla, með pví að rýna í sjónarhorn peirra, vonir og áskoranir. Leitast verður við að svara eftirfarandi rannsóknarspurningu: Hvaða áskoranir birtast sýrlenskum nemendum, foreldrum peirra og kennurum vegna náms og kennslu í íslenskum grunnskóla? Rannsóknin mun pannig veita kennurum og skólakerfinu almennt upplýsingar til að skilja parfir foreldra og nemenda sem koma sem flóttamenn auk pess að gagnast skólastjórnendum til að styðja við samstarf og efla samskipti og samræður milli heimilis og skóla.

Greinin er í fjórum hlutum. Fyrsti hluti felur í sér fræðilega samantekt um rannsóknarefnið og 1 öðrum hluta er gerð grein fyrir aðferðafræði og gagnagreiningu rannsóknarinnar auk siðferðilegra sjónarmiða. Driðji hluti inniheldur niðurstöður rannsóknarinnar og í peim fjórða eru umræður um niðurstöðurnar.

\section{Rannsóknir og fræðilegur bakgrunnur}

pegar flóttafólk kemur til móttökulands er algengt að pað komi í hópum. Рað gerir fólkið að augljósum minnihlutahópi, ekki síst ef hópurinn ber einkenni frá heimalandinu, til dæmis varðandi tungumál og menningu (Anderson, 2003). Ýmsar kenningar eru um pað ferli sem flóttamenn fara í gegnum pegar peir flytja búferlum til móttökulandsins og er aðlögunarkenning Berry (2005) ein peirra. Hann bendir á fjórar aðlögunaraðferðir sem tengjast tveimur meginatriðum, annars vegar hversu framarlega fólk forgangsraðar pví að viðhalda menningarlegum siðum sínum og menningarlegri sjálfsmynd og hins vegar vilja viðkomandi til að taka pátt í hinu stærra samfélagi ásamt öðrum pjóðfélagshópum. Hvað varðar flóttamennina er talað um að samlögun (e. assimilation) eigi sér stað pegar einstaklingar leggja ekki ofuráherslu á að viðhalda móðurmáli og menningarlegri sjálfsmynd og hafna henni jafnvel og sækjast frekar eftir að tileinka sér menningu móttökusamfélagsins. Aðskilnaður (e. separation) verður hins vegar pegar einstaklingar halda í eigin hefðir og forðast samneyti við aðra menningu (Berry, 2005). Í seinna tilfellinu tileinkar viðkomandi sér ekki ríkjandi tungumál eða gildi móttökulandsins heldur varðveitir frekar menningarlega siði sína (Anderson, 2003). Sampætting (e. integration) á sér stað pegar áhugi er fyrir að viðhalda eigin menningu en tileinka sér jafnframt menningu móttökusamfélagsins og eiga í daglegum samskiptum við aðra menningarhópa. Sampætting er talin vera sá kosturinn sem gefur jákvæðustu útkomuna. Sísti aðlögunarkosturinn er jaðarsetning eða aðskilnaður sem á sér stað pegar lítill sem enginn áhugi er fyrir að eiga samskipti við aðra hópa (Berry, 2005; Sheikh og Anderson, 2018). Í nýlegri rannsókn Evu Harðardóttur og Berglindar Rósar Magnúsdóttur (2018), um ríkjandi stefnur og strauma um ungt flóttafólk í íslenska grunn- og framhaldsskólakerfinu, kom fram að í stefnuskjölum birtist hugtakið aðlögun fyrst og fremst 1 formi aðgerða um að flóttafólk aðlagist íslenskum aðstæðum og samfélagi án pess að gert sé rád fyrir gagnkvæmri aðlögun íslensks samfélags. Slíkar áherslur eru í anda samlögunar (e. assimilation). Pá benda niðurstöður peirra til pess að skilningur á fjölbreytileika einstaklinga og samfélaga sé einsleitur, hópar skilgreindir á grundvelli trúar, menningar eða pjóðernis og pannig aðgreindir sem sérstakir hópar.

Einn meginhvati að aðlögun að samfélagi eru skólar, par sem peir miðla gildum, venjum og verkfærum tiltekinnar menningar. Аð auki eru skólar aðaltengiliðir milli innflytjenda og móttökusamfélagsins. Tveir pættir sem geta haft áhrif á ferli aðlögunar í skólum eru væntingar um hvernig eigi að haga sér í skólum og hversu lík eða ólík menning heimalandsins er menningu móttökusamfélagsins (Anderson, 2003). Dessari rannsókn er ætlað að stuðla að betri skilningi á reynslu sýrlenskra flóttabarna og foreldra peirra varðandi íslenska grunnskóla, sem og á reynslu kennara af samskiptum við pennan hóp. 
Í pessari grein er litið svo á að fjölmenning sé hugmynd sem felur í sér jafnrétti, hvetur til pess að menningarleg sjálfsmynd dafni og tryggir að einn hópur ríki ekki yfir öðrum (Castles, 2009). Hægt er að líta á skóla sem örmenningu sem samanstendur af ríkjandi menningu og ýmsum menningarkimum sem hafa sérstök viðmið, gildi og markmið (Banks, 2009).

Fjölmenningarleg menntun er leið til að bregðast við takmarkaðri aðlögun og aðskilnaði nemenda í skólakerfinu og greina hvaða áhrifavaldar pað eru sem birtast með neikvæðum formerkjum í menntakerfinu. Með pví að nota slíka nálgun er leitast við að nýta möguleika nemenda og viðurkenna ólíka stöðu peirra með pví að flétta saman og viðurkenna ólíka menningu ásamt að stuðla að auknu jafnrétti (Castles, 2009).

Að mati Banks (2013) felur fjölmenningarleg menntun í sér umbætur sem stuðla að jafnari tækifærum til menntunar fyrir ýmsa menningar-, pjóðernis- og efnahagslega hópa. Líta má á valdeflingu aðila í skólastarfi sem lið í slíkum umbótum, til dæmis samskipti og samstarf kennara, nemenda og foreldra (Nieto, 2009). Markvisst parf að vinna að pví að efla nemendur og hjálpa peim að verða virkir í skólasamfélaginu, og byggja á pekkingu og hæfni peirra í kennslu, til dæmis mállegum og menningarlegum páttum sem peir búa yfir. Í nýlegri íslenskri rannsókn (Anh-Dao Tran og Samúel Lefever, 2018) meðal nemenda af erlendum uppruna kemur fram að skólinn gerir lítið með pann mállega auð sem nemendur búa yfir í skólastarfinu og hann er ekki nýttur peim til framdráttar í námi. Pessu nátengt eru hugmyndir Gay (2010) um menningarmiðaða kennslu (e. culturally responsive teaching) en hún felur í sér að kennarar geri sér grein fyrir og skilji menningarlegan bakgrunn nemenda sinna og nýti sér hann í kennslu. Menningarmiðuð kennsla er auk pess tækifæri til að byggja brú milli heimila og skóla og skapa vettvang til að skilja staðbundna menningu skólans og fjölbreytileika heimilanna.

Ein leið til að efla menningarlegan skilning er að líta til starfs Hofstede um pjóðmenningu (Hofstede, 2011; Hofstede Insights, e.d.) en pjóðmenningarvíddir hans lýsa hvernig menning samfélags hefur áhrif á gildi meðlima pess og hvernig pau gildi birtast síðan í hegðun. Rannsóknir Hofstede eru gagnlegt tæki til að skilja og bera saman viðbrögð pátttakenda varðandi menntakerfið og námsumhverfið í tengslum við menningu. Hann bendir á sex víddir sem nota má til að skilja menningarleg gildi fólks sem tilheyra ólíkum pjóðlöndum (Hofstede, 2011). Dær eru valdafjarlægð, (e. power distance), undanlátssemi/agi (e. indulgence/ restraint), karllægni/kvenlægni (e. masculinity/femininity), einstaklingshyggja/heildarhyggja (e. collectivism/individualism), langtímahyggja/skammtímahyggja (e. long/short term orientation) og óvissuhliðrun (e. uncertainty avoidance).

Hvað menntakerfið varðar eru valdafjarlægð og karllægni/kvenlægni góð dæmi til að skilja betur hvernig menningarvíddir Hofstede geta birst. Í löndum par sem mikil valdafjarlægð ríkir, til dæmis í Sýrlandi, er menntun gjarnan kennaramiðuð, samband kennara og nemenda er formlegt og komið er fram við kennara af virðingu eða jafnvel ótta (G. Hofstede, G.J. Hofstede og Minkov, 2010). Í löndum par sem valdafjarlægð er hins vegar lítil, til dæmis á Íslandi, er menntakerfið miðað að nemendum, litið er á kennara og nemendur sem jafningja og nám er tvíhliða samskiptaferli (Hofstede o.fl., 2010). Í karllægum samfélögum er samkeppni mikil milli nemenda, afreksfólki á sviði menntunar er umbunað, sigur er mikilvægur og mistök ekki leyfð. Aftur á móti er samkeppni síður í hávegum höfð í kvenlægum samfélögum, mistök eru viðurkennd og peir sem purfa stuðning eða eru „minni máttar“ eru metnir að verðleikum (Hofstede, 2011; Hofstede o.fl., 2010). Ísland og Sýrland eru dæmi um andstæður hvað petta varðar.

Dróun á skýrum samskiptaleiðum milli heimilis og skóla getur dregið úr árekstrum vegna menningargilda og væntinga pegar flóttamenn eða fólk frá ólíkum menningarsvæðum byrjar í skóla (Hermína Gunnpórsdóttir, Barillé og Meckl, 2018; McGee Banks, 2010). Rannsóknir hafa sýnt að pátttaka foreldra í skólastarfi eykst í beinu hlutfalli við aukið aðgengi að skýrum samskiptaleiðum (Hamilton, 2003). Ýmis gögn og rannsóknir leggja áherslu á hið mikilvæga hlutverk sem samvinna heimilis og skóla og pátttaka foreldra leikur í velgengni flóttabarna 
(Block, Cross, Riggs og Gibbs, 2014; Ficarra, 2017; McBrien, 2005; Taylor og Sidhu, 2012; Thomas, 2016). Að auki er einn mikilvægasti pátturinn í að ná fram endurbótum í skólum og fjölmenningarlegri menntun pátttaka peirra sem standa nemendum næst í kennslu- og námsferlinu (Banks, 2009; Nieto og Bode, 2010). Í nýlegri norrænni rannsókn (Hanna Ragnarsdóttir, 2015) sögðust nemendur af erlendum uppruna í íslenskum grunnskólum eiga jákvæð samskipti við kennara sína og fannst peir velkomnir. Nemendur lýstu kennurum sínum sem umhyggjusömum, hjálplegum og góðum.

\section{Aðferðafræði}

Rannsóknin er eigindleg viðtalsrannsókn (Creswell, 2012) og tekin voru hálfstöðluð viðtöl (e. semi-structured) (Helga Jónsdóttir, 2013) við prjár sýrlenskar fjölskyldur og kennara barnanna. Hálfstöðluð viðtöl voru notuð par sem sú aðferð nær vel markmiði rannsóknarinnar um að skoða reynslu pátttakenda og gaf peim jafnframt tækifæri til að tjá skoðanir sínar og hugmyndir með eigin orðum (Esterberg, 2002).

\section{Dátttakendur}

Prjár sýrlenskar fjölskyldur, sem búa í sama sveitarfélagi og samanstanda af premur feðrum, premur mæðrum og sex börnum, tóku pátt sem sjálfboðaliðar á grundvelli eftirfarandi viðmiða: (1) teljast til kvótaflóttamanna, (2) búa utan höfuðborgarsvæðisins og (3) eiga að minnsta kosti eitt barn sem skráð er í grunnskóla á Íslandi. Allir feðurnir höfðu lokið framhaldsskólanámi í heimalandi sínu en mæðurnar höfðu takmarkaða menntun, ýmist óformlega eða grunnskólamenntun. Allir feðurnir og tvær mæður voru í vinnu pegar rannsóknin fór fram. Börnin, ein stúlka og fimm drengir, voru á aldrinum átta til 15 ára. Í fyrstu var leitað óformlega til foreldra, annaðhvort augliti til auglitis eða í gegnum síma, par sem rannsóknarmarkmið voru rædd og munnlegt sampykki peirra fengið fyrir pátttöku í rannsókninni. Eftir að munnlegt sampykki hafði fengist var foreldrum kynnt arabísk útgáfa af viljayfirlýsingu og skjali um upplýst sampykki. Börnin voru aðeins tekin í viðtöl eftir að sampykki peirra sjálfra hafði fengist, auk sampykkis foreldra peirra. Af persónuverndarástæðum verður fjölskyldunum og aðstæðum peirra ekki lýst frekar.

Skólastjórar voru beðnir um að benda á kennara sem kenndu sýrlenskum nemendum á grunnskólastigi. Tekin voru viðtöl við fimm kennara; fjórar konur og einn karl. Aðeins einn kennari hafði fyrri reynslu af að kenna flóttamönnum sem ekki voru skráðir formlega í skóla. Leyfi skólayfirvalda var fengið áður en samband var haft við skólastjóra. Kennarar fengu enska útgáfu af viljayfirlýsingu sem og skjal um upplýst sampykki. Staðsetning viðtala var val hvers kennara, ýmist skólastofa eða kaffihús.

\section{Gagnasöfnun og greining}

Sautján pátttakendur; prír feður, prjár mæður, sex börn og fimm kennarar, voru teknir í viðtöl einu sinni, vorið 2018. Einstaklingsviðtöl voru tekin við kennara og foreldra en hópviðtöl tekin við nemendur, par sem börn hafa tilhneigingu til að verða feimin í einstaklingsviðtölum og finnast slíkar aðstæður yfirpyrmandi eða ópægilegar (Fife, 2005). Systkini innan sömu fjölskyldu voru ýmist tvö eða prjú í hverjum hópi nema að einn nemandi var pó tekinn í einstaklingsviðtal par sem hann var sá eini í sinni fjölskyldu. Viðtöl við nemendur og foreldra fóru fram á arabísku á heimilum peirra en viðtöl við kennara fóru fram á ensku í skólunum, par sem sá rannsakandi sem tók viðtölin er ekki mælandi á íslensku en talar hins vegar ensku og arabísku.

Fjölskyldurnar voru fyrst teknar í viðtöl og eftir fyrsta stigs greiningu á peim viðtölum voru pau lögð til grundvallar við gerð viðtalsramma fyrir kennarana. Reynt var að einfalda spurningar til barnanna og myndir og kvarðar notuð til að auðvelda peim að svara. Sem dæmi voru nemendur beðnir að velja milli ýmissa andlita (til dæmis hamingjusams andlits eða sorgmædds andlits) sem 
gæfu til kynna líðan peirra í skólanum. Deir voru einnig beðnir að teikna hvernig peir vildu hafa draumaskólastofuna sína (til dæmis sætaskipan).

Öll viðtöl stóðu yfir í 30 til 60 mínútur og voru hljóðrituð. Viðtöl við foreldra og nemendur, sem voru á arabísku, voru pýdd strax og umrituð yfir á ensku.

Gögnin voru greind með pemagreiningu (Vaismoradi, Turunen og Bondas, 2013) par sem leitast var við að fanga raunveruleika pátttakenda (Braun og Clarke, 2006). Við fyrsta yfirlestur var opinni kóðun beitt, sem felur í sér að leita eftir sameiginlegum práðum í frásögn viðmælenda sem höfðu samsvörun við markmið rannsóknarinnar og rannsóknarspurninguna. Dví næst voru sjónarmiðin sem fram komu við kóðunina flokkuð saman og meginpemu mynduð pvert á viðtölin.

\section{Siðferðileg sjónarmið og áskoranir}

Allir pátttakendur voru upplýstir um að pátttaka peirra væri valfrjáls og að peir gætu hætt pátttöku hvenær sem væri. Deim var einnig tilkynnt um hljóðritunina. Útprentuð eintök af yfirlýsingum um upplýst sampykki og viljayfirlýsingum voru skilin eftir í höndum foreldranna en rannsakendur héldu eftir stafrænum afritum. Í tilfelli kennaranna var pað öfugt; upplýst sampykki var skannað og pað sent til peirra með tölvupósti. Fyrir viðtölin fengu kennararnir einnig senda viljayfirlýsingu með tölvupósti.

Rannsakendur voru meðvitaðir um að í öllu rannsóknarferlinu og í niðurstöðum yrði ekki hægt að bera kennsl á pátttakendur. Dulnefni voru pess vegna notuð um pátttakendur. Rannsakendur forðuðust einnig að nefna atriði eins og nöfn á skólum, tímabil sem pátttakendur bjuggu í Líbanon og hver fæðingarborg peirra væri. Í págu nafnleyndar var litið á alla nemendur sem karlkyns og alla kennara sem konur pegar gögnin voru greind, par sem kyn var ekki breyta í pessari rannsókn. Vísað var til foreldra með gerviættarnöfnum. Pau eru: Herra og frú Faraj, herra og frú Loutfi og herra og frú Zain. Bæði nemendur og kennarar fengu gervinöfn. Nöfnin sem nemendunum voru gefin voru Adam, Alaa, Bilal, Moussa, Nadim ogWael og nöfnin sem kennararnir fengu voru Dagmar, Dana, Emma, Kristín og Lísa.

Nokkrar áskoranir komu fram varðandi tungumálanotkun pegar reynt var að varðveita ákveðna merkingu í orðalagi, til dæmis arabísk spakmæli. Brugðist var við pessum takmörkunum með pví að skrifa minnispunkta til að skýra merkinguna. Annað atriði varðandi tungumálanotkun var að sá rannsakandi sem tók viðtölin talar arabísku og ensku og notaði arabísku við foreldra og börn en ensku í viðtölunum við kennarana.

\section{Niðurstöður}

Í pessum hluta eru niðurstöður rannsóknarinnar kynntar undir premur meginpemum: (1) Að skilja ný viðmið um nám og kennslu, (2) Hlutverk samskipta og ábyrgð, og (3) Er Ísland hluti af framtíðinni? Fyrsta pemað samanstendur af premur undirpemum, sem eru: Einstaklingsmiðuð kennsla og námsárangur, Gildi list- og verkgreina, og Agi, heimanám og virðing sem grunnur að námi.

\section{Að skilja ný viðmið um nám og kennslu}

Undir pessu pema birtust nokkur undirpemu sem hafa frekari skírskotun til pess hvernig viðmælendur upplifðu og skildu ýmsa grunnpætti í námi og kennslu. 


\section{Einstaklingsmiðuð kennsla og námsárangur}

Á Íslandi er opinber menntastefna byggð á hugmyndafræðinni um skóla án aðgreiningar og leitast er við að einstaklingsmiða kennslu. Nemendur vinna að markmiðum sínum og fá til pess viðeigandi aðstoð. Í öllum viðtölunum við foreldrana kom fram að peim fannst erfitt að skilja hvernig nám án aðgreiningar, einstaklingsmiðuð kennsla og mat á námsárangri virkaði. Frú Loutfi fannst til dæmis erfitt að skilja pað fyrirkomulag að hafa alla nemendur saman í einni skólastofu prátt fyrir mismunandi eiginleika peirra, getu og færni.

Foreldrunum, sem voru vanir annars konar matskerfi, til dæmis tölueinkunnum og prófum, fannst sérstakt að sett voru einstök markmið fyrir hvern nemanda. Herra Loutfi sagði að hann „pyrfti að sjá árangur barna sinna“ og velti pví fyrir sér að ef „,рað er eitthvað sem kallast próf, könnun eða annað álíka (...) hvar er árangurinn?“. Herra Faraj efaðist pess vegna um námsmat kennaranna.

Dar sem ekkert talnaeinkunnakerfi er notað upplifa foreldrarnir sig týnda pegar kemur að eftirliti með námsframvindu barna sinna. Enn fremur leggja foreldrarnir áherslu á mikilvægi samkeppni til að hvetja nemendur til að leggja meira á sig. Frú Faraj útskýrði petta með pví að segja:

Við [með vísan til sýrlenska og arabíska samfélagsins] höfum keppnisskap, til dæmis, ef einn nemandi fær einkunnina 10 pá mun hinn nemandinn vilja fá sömu einkunn (...) svo barnið vill leggja meira á sig og læra heima.

Herra Zain nefndi petta atriði einnig með pví að bera pað saman við heimalandið:

Detta var svona í Sýrlandi, til dæmis, verðlaunið fyrstu tíu, pá munu peir sem eru verðlaunaðir alltaf bæta sig og vinir peirra reyna að halda í við efstu nemendurna (...) og petta hafa pau ekki hér.

Foreldrarnir upplifðu skort á samkeppni sem veikleika kerfisins par sem nemendur gætu ekki fallið um skólaár, eða líkt og herra Loutfi lýsti pví: „Баð er ekkert mat“ vegna pess að „,nemandinn, hvað sem hann er, hann mun standast [flytjast upp um bekk].“

Börnin nefndu hins vegar engar truflanir eða áskoranir varðandi pennan pátt. Pau töldu kennara sína hjálplega. Aðspurð um hvernig tengsl peirra væru við kennara sína voru sum svör peirra á pessa leið:

Bilal: Gott ef ég vil fá hjálp, hjálpa peir mér.

Moussa: Framkoma peirra er mjög góð (...) peir koma einir til mín og hjálpa mér, ef mig vantar eitthvað.

Degar Alaa var sýndur kvarði af broskörlum, og var beðinn um að benda á pað andlit sem best gæfi til kynna hversu ánægður hann væri með kennara sinn, valdi hann sömuleiðis mjög glaðan broskarl. Skýring hans á pessu var „,[vegna pess að] peir hjálpa mér“ eða, eins og Nadim sagði, „peir koma mjög vel fram við mig.“ Sumir foreldranna kunna einnig að meta petta, eins og herra Faraj benti á:

Til dæmis taka peir tillit til pess ef hann [sýrlenski nemandinn] er veikur eða á við sálræn vandamál að stríða (...) peir [kennararnir] skilja nemandann ekki eftir einan (...) peir finna lausn fyrir hann.

Gildi list- og verkgreina

Í Ađalnámskrá grunnskóla á Íslandi er vikulegt hlutfall list- og verkgreina 15,48\%, sem er hærra en hlutfall stærðfræði (14,88\%) og náttúruvísinda (8,33\%). List- og verkgreinar eru skilgreindar sem 
hér segir: „Undir listgreinar heyra tónmennt, sjónlistir og sviðslistir. Undir verkgreinar heyra hönnun og smíði, textílmennt og heimilisfræði“ (mennta- og menningarmálaráðuneyti, 2013, bls. 52).

Degar rætt var um námsgreinarnar við foreldra kom í ljós að peir höfðu annan skilning á hlutverki list- og verkgreina en fram kemur í aðalnámskránni. Frú Loutfi hafði pá skoðun að pessar greinar væru ,afpreying“, sem ,gagnast ekkert“ miðað við námsgreinar, svo sem ensku, sem veittu meiri „,pekkingu“. Á sama hátt lýsti herra Zain eftirfarandi yfir: „(...) vísindagreinarnar, pað lítur út fyrir að peir [skólar á Íslandi] hafi ekki áhuga á peim." Hann varði pessa yfirlýsingu sína með pví að bera skólann saman við pann í Sýrlandi og sagði:

Ég er að tala um stöðuna í Sýrlandi - eðlisfræði og efnafræði voru góð og pau einbeittu sér mikið að peim. Núna er staða barna minna verri (...) pau eru enn ung. En [til dæmis] í landafræði og landfræðilegum hnitum (...) komdu með kort og spurðu barnið hvar er Bretland og hann mun ekki vita hvar, en í Sýrlandi petta var í kennslutímum (...), peir settu kortið og sögðu okkur petta er Egyptaland (...) við vissum hvernig æetti að staðsetja allt á kortinu. Ég er viss um að enginn veit núna hvernig á að staðsetja neitt á korti.

Andstætt við sjónarmið foreldranna lögðu kennararnir áherslu á mikilvægi list- og verkgreina meðal annars til að auka sköpunargáfu og að kenna börnunum að hugsa um sig sjálf. Kristín útskýrði petta með pví að segja:

Okkur finnst mjög mikilvægt að kenna peim pað [listir og verkgreinar]. Með pví kennum við peim að vera skapandi, búa til eitthvað, fá hugmyndir, vera ekki bara eins og tölvur og gera aðeins pað sem kennararnir segja pér.Vera skapandi. Hugsa sjálfstætt.

Að auki lögðu kennarar áherslu á gildi list- og verkgreina pegar kæmi að pví að uppgötva sjálfan sig. Lísa útskýrði pað nánar með pví að segja:

Nemendur eru bara fólk með mjög mismunandi hæfileika. Ég hef fengið nemendur sem eru ófærir um að vinna stærðfræði, peir hafa ekki getu til pess, pað er mjög erfitt, en á sama tíma eru peir framúrskarandi í ípróttum, dansi eða öðru. Рað er bara pannig að styrkleikar fólks eru mismunandi og í grunnskóla er mikilvægt að fá tækifæri til að vinna bæði með huga og hönd. Til að finna hvar styrkleikar pínir liggja.

Allir nemendurnir höfðu gaman af list- og verkgreinunum. Til dæmis tjáði Nadim sig um pað að hans hugmynd um fullkominn skóla væri „eins og skólinn okkar [núverandi skóli]“. Degar hann var spurður hvers vegna pað væri útskýrði hann:

Dað er saumað, smíði, teikning og pannig. Hlutir eins og leir. Pað er tónlist, ípróttir. Hvað sem pú vilt að sé. Đað er eldað.

Á sama hátt benti Alaa á að pað sem hvetur hann til að læra er „trésmíði og saumar,“ og Wael lýsti hvernig honum líkaði núverandi skóli með pví að bera hann saman við skóla í Sýrlandi: „Ekki eins og Sýrland. Sýrland [snýst] allt um að læra. Dað eru engir saumar, smíðar“.

Agi, heimanám og virðing sem grunnur að námi

Agi er annað dæmi sem endurspeglar hugmyndir foreldranna um hvernig skóli á að vera. Sýrlensku foreldrarnir töldu að íslensku skólana skorti aga og reglu og að nemendur sýndu kennurunum sínum litla virðingu. Til dæmis nefndi frú Faraj að pau „finni ekki fyrir reglunni“ og báru skólann saman við pá í Sýrlandi og Líbanon með pví að segja:

Dað er ekki eins og í Líbanon (...) pað er regla [í Líbanon], barnið er hreint og fint.

Hann gengur í skóla klæddur einkennisbúningi skólans og hárið snyrtilegt og vel greitt, neglurnar klipptar og fötin straujuð og hrein. Hér er ekkert slíkt. 
Að auki lýsti eiginmaður hennar, herra Faraj, pví yfir að skólakerfið á Íslandi væri „,mjög mikið frjálst“ í samanburði við Sýrland, par sem pað er „strangara“. Degar hann var spurður hvað hann meinti með pví útskýrði hann:

Til dæmis, ef nemandinn er ekki undirbúinn, veit hann að honum verður refsað. Svo hann vinnur betur og gæetir betur að sér. Hér, til dæmis, hvort sem hann er undirbúinn eða óundirbúinn veit hann að niðurstaðan verður sú sama.

Síendurtekin dæmi, sem nokkrir foreldrar gáfu til að lýsa ætlaðri vanvirðingu nemendanna við kennara sinn, svipaði til pessarar tilvitnunar í orð frú Faraj:

Í okkar landi situr nemandinn og sýnir virðingu og mannasiði, hér situr nemandinn og setur fæturna upp á borð fyrir framan kennarann og vini sína. Detta er eðlilegt fyrir peim. Við höfum petta ekki. Í okkar landi purfa nemendur (...) að sitja og hegða sér vel og beina athygli sinni að kennaranum á meðan hann útskýrir verkefnin.

Aðeins einn nemandi, Moussa, minntist á meintan skort á aga í viðtölunum. Moussa sagði að „kennslan“ væri staður framfara í skólanum. Degar hann var beðinn að útskýra petta betur svaraði hann pví að „til dæmis, pegar við eigum að vera að læra er einn nemandi að leika sér, annar í símanum og enn annar ekki að skrifa“. Hann sagði jafnframt að hann saknaði „barsmíðanna [líkamlegra refsinga]“ í Sýrlandi, vegna pess að pannig „lærir einstaklingurinn tafarlaust“.

Andstætt svörum pessa nemanda gáfu allir hinir nemendurnir til kynna að peir veldu íslensku kennarana fram yfir pá í Sýrlandi og Líbanon, par sem barsmíðum var beitt. Nadim lýsti pví yfir að ,„áður hataði hann pað sem kallað var skóli,“ vegna pess að pað var ,endalaust að læra og par var barið.“ Einnig útskýrði Bilal að honum líkaði mjög vel við núverandi kennara sinn af pví að „hún verður ekki reið og öskrar“.

Kennarar voru meðvitaðir um viðhorf foreldranna til kennsluaðferða sem byggja til dæmis á utanbókarlærdómi og einstaklingsprófum. Peirsögðust ekki vera hlynntir slíkum kennsluaðferðum en vildu pess heldur leggja áherslu á að byggja upp traust og skapa opin samskipti við nemendurna. Kristín lýsti skoðun sinni með pví að segja:

Við erum að reyna að (...) láta peim líða vel. Láta pá treysta okkur og láta peim finnast peir velkomnir (...) fyrir börnin ef pað kemur ekki frá peim sjálfum, læra peir pað ekki, pað er mjög erfitt að láta suma [nemendur] læra eitthvað sem peir vilja ekki læra (...). Mitt álit er að reyna að skapa góða manneskju, ekki láta fólk hlýða með pví að hræðast pig. Láttu pau langa að fylgja reglunum, af pví pað er betra.

Lísa lýsti andstöðu sinni varðandi skoðanir foreldranna á aga á sama hátt og lagði áherslu á samskipti til að leysa átök á milli nemenda með pví að fullyrða:

Deir [sýrlensku foreldrarnir] telja að við séum ekki nógu ströng pegar kemur að aga og halda að við tökum ekki nógu vel á pví pegar hann [sýrlenski flóttamaðurinn] hefur verið lagður í einelti eða eitthvað. En, ég er ósammála, vegna pess að nemandi minn hafði раð viðhorf að ef að einhver var að abbast upp á hann, eða einhver var að berja, mætti hann berja til baka, en við vorum að reyna að innprenta hjá honum að við reynum að nota orð og við reynum að tala um hlutina og leysa pá án pess að berja til baka.

Mismunandi sjónarmið foreldra og kennara endurspegla pví ólíkar skoðanir varðandi áherslur í námi og kennslu.

Allir foreldrarnir létu í ljós pá löngun sína að börn peirra fengju heimanám og töldu pað nauðsynlegt til að fylgjast með námi peirra og til að vera fullvissir um að börnin væru að læra. Sem dæmi nefndi frú Faraj að heimanám væri mikilvægt til að tryggja að „hugmyndinni verði sád í huga hans [nemandans]". 
Að auki sagðist hún hafa nokkrum sinnum óskað eftir heimanámi, en samkvæmt henni væru „,peir ekki að gefa peim heimanám.“ Hún bætti síðan við: „Đau sögðu að hér á Íslandi sé petta svona. Баð [námið] er nóg í skólanum, og heima stunda peir [nemendurnir] aðra afpreyingu“.

Kennararnir lögðu áherslu á mikilvægi pess að nemendur eyddu tíma sínum eftir skóla með fjölskyldum sínum og í afpreyingu. Lísa útskýrði petta með pví að bera saman skóla og venjulegt starf. Hún sagði:

Við höfum [pá skoðun að] petta er peirra [nemendanna] vinna, og vegna pess að ég vil ekki taka vinnuna mína með heim sendi ég pá ekki heim með sína vinnu.

Drátt fyrir að foreldrar hafi talið að börn peirra fengju lítið sem ekkert heimanám kom í ljós í viðtölum við kennara að peir úthluta nemendum verkefnum til að vinna heima. Kennarar bentu á að gert væri ráð fyrir að nemendur lykju peim verkefnum heima sem ekki er lokið í kennslustofunni. Enn fremur bentu allir kennararnir á að börnin yrðu að lesa heima, par sem Dagmar nefndi að „,pau væntu pess að foreldrar létu bau [nemendurna] lesa upphátt á hverjum degi“ og Kristín sagði að „,foreldrarnir pyrftu að skrifa nöfn sín [til að segja að] pau hlustuðu á pá lesa." Foreldrarnir virtust ekki telja petta til heimanáms.

\section{Eðli samskipta og ábyrgð}

Í viðtölum foreldra og kennara kom í ljós að samskipti milli foreldra og skóla áttu sér helst stað á reglulegum fundum foreldra og kennara, sem fram fara tvisvar á ári. Tvær fjölskyldur sögðust halda sambandi við skólann með tölvupósti. Faraj-fjölskyldan nefndi að hún hefði ekki fengið tölvupóst og frú Faraj sagði að pau héldu sér upplýstum í gegnum „tölvupóst barna sinna; til dæmis, ef pað er frí senda peir [upplýsingarnar] í tölvupóst barnanna“.

Kennarar vildu meina að foreldrarnir svöruðu ekki tölvupóstunum og efuðust jafnvel um að peir hefðu lesið pá. Deir sögðust nota ensku í tölvupóstunum og gerðu pess vegna ráð fyrir að peir gætu skilið póstana en fengju engin svör til baka. Túlkar væru notaðir takmarkað en Dana sagðist hafa reynt pað tvisvar. Kennararnir virtust efast um að foreldrarnir skildu hvað væri skrifað í tölvupóstunum. Emma sagðist gjarnan vilja að foreldrar tækju meiri pátt í skólanum og tengdi skort á pátttöku peirra við skort á tungumálakunnáttu. Kristín taldi muninn á menningarlegum gildum vera hindrun í samskiptum og pegar hún ræddi um leiðir til að efla skilning foreldra á íslenska kerfinu sagði hún:

(...) Рað gagnast ekkert að reyna að láta hann [sýrlenskan föður] skilja (...). Túlkurinn okkar er mjög góður í að hjálpa honum að skilja reglurnar okkar, og pað er mikið auðveldara fyrir hann að gera pað, af pví hann er karlmaður. Pað er líka menningarmunur (...) maðurinn ræður á sínu heimili. Pannig er pað ekki á Íslandi, við reynum að vera jafningjar, en pegar maður segir eitthvað svona við mann, pá er betra fyrir manninn að segja honum frá. Ég veit að hann er ekki að fara að hlusta á mig. Svo ég brosi bara.

Að mati kennaranna voru mæðurnar hlutlausari en feðurnir í samskiptum við pá, jafnvel pó að túlkur væri til staðar á fundum, en petta samræmist pví sem mæðurnar nefndu sjálfar um að feðurnir væru ábyrgir fyrir tölvupóstinum.

Af hálfu skólans og kennara virtust engin önnur úrræði en að fá túlk vera notuð til að efla samskipti við foreldrana. Aðspurð hvort skólinn hefði gert einhverjar frekari ráđstafanir til að fá foreldrana til að taka pátt svaraði Emma „nei.“ Hún sagði pví næst að pað væri aðeins ein manneskja sem héti Anna (dulnefni) og væri tilnefnd af sveitarfélaginu sem ,sæi um pær“ [sýrlensku fjölskyldurnar]“ og að allt sem viðkæmi flóttamönnunum væri „bara hennar ábyrgð.“ Hún taldi að Anna væri „samskiptamanneskjan“ sem starfsfólk skólans sendi tölvupóst pegar pað lenti í vandræðum með flóttamennina en einnig varðandi námsefni. Kristín nefndi að foreldrarnir væru alltaf velkomnir í skólann og pau byðu foreldrum að koma og sjá hvað pau væru að gera. Í byrjun hefðu peir 
komið oft en pað hefði breyst. Allir foreldrarnir fullyrtu að peir væru ekki í neinu sambandi við foreldra bekkjarsystkina barna sinna, nema hinna sýrlensku barnanna. Aðeins einn kennari, Emma, minntist á mikilvægi pess að vera í sambandi við aðra foreldra og sagði:

Við hugsum að kannski af pví að peir eru að reyna að verða hluti að samfélaginu ættu peir kannski að koma. Eins með vini fyrir börnin eftir að skóladegi lýkur, pá parftu að kynnast hinum foreldrunum. Pess vegna verður pú að koma í skólann.

Ábyrgð foreldranna um að taka pátt virðist vera varpað yfir á pá. Kennarar nefndu að gott væri ef foreldrarnir heimsæktu skólann oftar og ættu í samskiptum við íslenska foreldra, en ekki var pó bent á neinar sérstakar leiðir til að auka samskipti peirra.

\section{Er Î́sland hluti af framtíðinni?}

Foreldrar voru ekki vissir um hvort peir sæju börn sín fyrir sér i íslenskum háskólum í framtíðinni. Helsta ástæða pess tengdist vantrausti peirra til íslenska menntakerfisins. Til dæmis lagði frú Loutfi áherslu á að börn hennar yrðu ekki í íslenskum háskólum. Eiginmaður hennar sagðist hafa áhyggjur af óvissu með framtíð barna sinna í tengslum við skort á skipulagi i íslenskum skólum. Hann rökstuddi pað svona:

Hvenær munu pau [börnin hans] komast í háskóla, við vitum pað ekki, vegna pess að handhafi áætlunarinnar [sem pýðir kennarinn eða skólastjóri] veit pað ekki (...) Nú [ef] ég fer (...) í framhaldsskólann og spyr hann [kennarann] hvenær munu peir klára, hann svarar hreinskilnislega að hann viti pað ekki (...). Раð ætti að vera pannig varðandi flóttamenn (...) er vitað [að eftir] prjú ár hann [nemandinn] mun klára petta stig, fjögur ár petta stig og svo fimm ár petta stig, svo hann [nemandinn] viti hvernig hann getur skipulagt líf sitt.

Að auki, pegar hann var spurður hvar hann sæi fyrir sér að börn hans yrðu eftir fimm til sjö ár héðan í frá, fullyrti herra Faraj að „á Íslandi [er pað] erfitt (...) fyrir skólana, fyrir tungumálið, fyrir allt. Deir segjast vera ofarlega um heim allan fyrir kennslu[gæði], en við sjáum petta ekki. Til dæmis, læknarnir [á Íslandi] peir hafa allir lært í Kanada, Ameríku, í Bretlandi“.

Löngun foreldranna til að börn peirra yrðu langskólagengin í öðrum löndum en á Íslandi skýrir áherslu peirra á mikilvægi pess að læra ensku. Frú Zain nefndi að „,pau [börnin hennar] ættu að taka ensku“ vegna pess að „,petta tungumál er pað besta hvert sem pú ferð.“ Enn fremur lýsti frú Loutfi vonbrigðum sínum yfir pví að ekki væri næg áhersla lögð á ensku í skólanum: „Deir vilja ekki að hann tali ensku í skólanum, peir vilja íslensku.“

Kennararnir voru meðvitaðir um löngun foreldranna til að yfirgefa Ísland í framtíðinni. Engu að síður komu peir ekki auga á að vantraust foreldranna á íslensku skólakerfi væri meginástæða pess að peir vildu yfirgefa landið, heldur væru pað áhrif tungumálsins og nærsamfélagsins. Til dæmis benti Lísa á að ástæðan fyrir pví að sýrlensku fjölskyldurnar vildu fara væri sú að „,arabíska samfélagið er ekki (...) stórt“" og pær práðu að vera í landi par sem „pær eiga (...) ættingja.“ Emma benti einnig á að sýrlensku fjölskyldurnar gæti langað að fara til lands par sem „,pær geta talað ensku“, svo sem til Englands.

Allir nemendurnir nema einn sögðust vilja flytja til annars lands en fóru ekki náið út 1 ástæður pess að peir vildu gera pað. Aðeins tveir nemendanna sögðu frá ástæðum löngunnar sinnar til að fara, en pær voru tengdar tungumálinu og umhverfinu. Alaa sagðist langa að flytja til „Ástralíu“ par sem „pau [fólkið] tala ensku“ og Nadim sagðist ekki vilja vera á Íslandi par sem pað væri svo ,kalt". 


\section{Umræða}

Demun sem sett voru fram í niðurstöðunum eiga sér sameiginlegan práð sem ræddur verður sérstaklega en pað er menningarmunur sem birtist pó með ólíkum hætti í máli viðmælenda. Dessar birtingarmyndir verða ræddar í ljósi kenninga og fræðilegra skrifa.

Ólík viðhorf til náms og kennslu

Dað kom berlega fram í viðtölum við pátttakendur að væntingar foreldranna til skólakerfisins eru ólíkar ríkjandi skipulagi og vinnubrögðum í skólum nemendanna. Væntingar foreldranna áttu sér rætur í samanburði peirra á menntakerfi Íslands annars vegar og heimalands peirra, p.e. Sýrlands eða Líbanons, hins vegar. Í viðtölunum við nemendur kom pessi samanburður einnig fram en öfugt við foreldra sína kusu nemendurnir íslensku skólana umfram pá sýrlensku. Deim líkaði betur hvernig íslensku kennararnir komu fram við pá, sögðu pá umhyggjusamari og ekki eins stranga og peir nutu námsgreina á borð við list- og verkgreina, en foreldrarnir töldu hins vegar að slíkar greinar hefðu lítið gildi fyrir menntun barna sinna. Ánægja nemendanna rímar vel við fyrri niðurstöður um jákvæð samskipti nemenda og kennara og líðan nemenda (Hanna Ragnarsdóttir, 2015).

Foreldrarnir óskuðu eftir námsumhverfi par sem meiri agi og regla ríkti. Deim fannst íslensku skólarnir mjög ,frjálsir", í peirri merkingu að agi og reglufesta væri lítil, og töldu kennarana ekki nógu stranga. Að auki óskuðu peir eftir kerfi sem hvetti til samkeppni milli nemenda og byggðist á hugmyndinni um að lakur árangur leiddi til falls og að nemendur pyrftu jafnvel að endurtaka bekki. Foreldrarnir vildu umbuna afreksnemendum og/eða hafa refsikerfi sem hvatningu til náms. Detta endurspeglaðist einnig í væntingum eins nemanda, sem óskaði eftir líkamlegri refsingu pví pað myndi hvetja nemendur til að læra meira. Dvert á móti lögðu kennararnir áherslu á að nemendur lærðu vegna innri ánægju. Deir voru andsnúnir hugmyndum um samspil frammistöðu og samkeppni, sýndu hverjum nemanda hluttekningu og töldu ósanngjarnt að bera nemendur saman. Að auki lögðu kennarar áherslu á mikilvægi opinna samskipta til að leysa vandamál frekar en að beita refsingum og höfnuðu algerlega hugmyndinni um líkamlega refsingu.

Dessi andstæðu sjónarmið varðandi námsumhverfið endurspeglast í pjóðmenningarvíddum Hofstede, en samkvæmt peim einkennist menningin á Íslandi af lítilli valdafjarlægð og lítilli karllægni í samanburði við Sýrland sem mælist mjög karllægt og hefur mikla valdafjarlægð í líkani Hofstede (Hofstede Insights, e.d.). Samkvæmt Hofstede o.fl. (2010) eru mistök frekar viðurkennd í kvenlægum samfélögum (pað er löndum með litla karllægni), almennt ekki hvatt til samkeppni og peir sem teljast „,minni máttar“ virtir að verðleikum. Hins vegar er gjarnan hvatt til samkeppni 1 karllægum samfélögum, mistök eru síður sampykkt og afreksfólki er umbunað (Hofstede o.fl., 2010). Enn fremur má sjá í löndum með litla valdafjarlægð að námsferlið einkennist af tvíhliða samskiptum, par sem nemendur og kennarar eru jafningjar, líkamlegar refsingar eru ekki liðnar og teljast brot á lögum gagnvart börnum. Aftur á móti er frekar komið fram við kennara af virðingu og ótta í löndum með mikla valdafjarlægð, líkamlegar refsingar eru viðurkenndar og strangar reglur gilda í kennslustofum (Hofstede o.fl., 2010).

Auk gagnrýni foreldranna á námsumhverfið voru peir óánægðir með hve mikil áhersla var lögð á list- og verkgreinar, fannst pær vera ,aukanámsefni“ og vildu að skólarnir einbeittu sér meira að námsgreinum sem veittu ,,pekkingu“ að peirra mati, líkt og ensku og raungreinum. Deir töldu að kröfur til nemenda væru almennt ekki miklar. Kennarar mátu list- og verkgreinar hins vegar mikils og lögðu áherslu á vægi peirra fyrir nemendur til að uppgötva styrkleika sína og auka sköpunargleði og sjálfstæði. Á petta er lögð áhersla í Ađalnámskrá grunnskóla, par sem sköpun er ein af peim sex stoðum sem liggja til grundvallar skólastarfi og opinberri menntastefnu. Í námskránni er lögð áhersla á mikilvægi pess að skapa sjálfstæða einstaklinga og próa hæfileika og hæfni hvers nemanda (mennta- og menningarmálaráðuneyti, 2013). 
Í íslenska skólakerfinu er pví lögð áhersla á að nemendur séu sjálfstæðir og uppgötvi eigin vitsmunalegar leiðir að námi en samkvæmt (Hofstede o.fl., 2010) er pað einkenni á menningu landa sem eru með litla valdafjarlægð. Sjónarmið foreldranna endurspegla hins vegar ekki slíkar áherslur og eiginleika og mat peirra á gildi pessara námsgreina fyrir börn sín er andstætt mati kennaranna. Sýrland er land með sterka óvissuhliðrun og formgerð, og skýrleiki og reglur eru mikilvægir pættir fyrir einstaklinga í slíku samfélagi á meðan ófyrirsjáanlegar og óljósar aðstæður eru ópægilegar (Hofstede, 2011; Hofstede o.fl., 2010). Margt í líkani Hofstede er pví gagnlegt til að skilja sjónarmið og kröfur foreldranna, til dæmis um aga, námsárangur og heimanám, en meginástæða foreldranna fyrir pví að vilja fá aukið heimanám er að „fylgja eftir“ og ganga úr skugga um að börn peirra séu að læra. Рað getur einnig skýrt kvíða eins föðurins um námslega framtíd barna hans og gremju hans vegna skorts á skýrri langtímaáætlun frá kennurunum og skólunum um námsframvindu og námslok.

\section{Samskipti sem toekifari til sampattingar}

Niðurstöðurnar endurspegla hvernig menning samfélags getur haft áhrif á menntun, viðhorf og gildi einstaklinga. Menning er dynamísk, sem pýðir að hún er í stöðugri próun vegna pólitískra, félagslegra og ýmissa annarra pátta í umhverfi mannsins (Nieto, 2009). Menningarvíddir Hofstede eru aðeins ein leið að menningarlegum skilningi (Hofstede, 2011) en mikilvægt er jafnframt að vera gagnrýninn á túlkunina og forðast að skapa staðalímyndir pegar vísað er til peirra.

Sjónarmið foreldranna um nám og kennslu og hlutverk menntakerfisins eru hugsanlega ein ástæða pess að foreldrarnir bera takmarkað traust til íslenska skólakerfisins. Dessi staða getur leitt til neikvæðs aðlögunarferlis og haft í för með sér að flóttamannafjölskyldurnar annaðhvort einangrast eða verða jaðarsettar (Berry, 2005; Sheikh og Anderson, 2018). Í viðhorfum foreldranna endurspeglast ákveðnar efasemdir um mikilvægi pess að læra íslensku, sérstaklega í ljósi pess að peir sjá ekki fyrir sér að búa á Íslandi til lengri tíma. Að auki geta skoðanir foreldranna haft áhrif á viðhorf barnanna (McBrien, 2005), sem gæti skýrt væntingar sumra peirra um að flytja til annarra landa.

Skólar, sem gegna mikilvægu hlutverki í að auðvelda aðlögunarferli að nýju samfélagi, purfa pess vegna að taka frumkvæði og ábyrgð við að hlúa að sampættingu og draga úr neikvæðum áhrifum menningarlegar aðlögunar (McGee Banks, 2010). Samkvæmt Berry er heppilegasta leiðin til að ná sampæettingu sú að fylgja fjölmenningarlegri nálgun (Berry, 2005) en hún krefst pess að kennarar fái pjálfun til að takast á við fjölbreytileika (Anderson, 2003) og læra um menningarlegan bakgrunn og aðstæður flóttamanna. Niðurstöður pessarar rannsóknar benda hins vegar til pess að kennararnir hafi ófullnægjandi pekkingu á menningu flóttafólksins, sem getur hindrað námslega aðlögun flóttabarnanna (Lerner, 2012). Niðurstöðurnar benda til pess að kennarar varpi ábyrgðinni á foreldrana og að hindranir í samskiptum séu einhliða tengdar foreldrunum, til dæmis vegna menningarmunar og skorts á tungumálakunnáttu. Nauðsynlegur páttur fjölmenningarlegrar menntunar er að skólar axli ábyrgð og komi á skýrum samskiptaleiðum milli heimilis og skóla (McGee Banks, 2010). Enn fremur getur pað dregið úr menningarlegum árekstrum (Hamilton, 2003) ef kennarar leggja sig fram um að kynnast og skilja menningu nemenda og foreldra. Kennarar nefna að peir vilji læra meira um menninguna enda viti peir mjög lítið um sýrlenska menningu, eins og fram komi í máli Emmu sem sagði: „Kannski vitum við ekki nógu mikið um menninguna. Kannski ættum við að læra meira“.

Hamilton (2003) fjallar um mikilvægi pátttöku foreldra við að koma á skýrum samskiptaleiðum milli heimilis og skóla. Hann lýsir pessum tengslum sem gagnkvæmum par sem aukin pátttaka foreldra getur leitt til traustari samskipta. Í skrifum Hamilton (2003) er bent á að pví meiri sem pátttaka foreldra er innan skóla, pví betri verður skilningur peirra á skólanum og starfsháttum hans. Niðurstöður pessarar rannsóknar sýna að pátttaka foreldra í skólanum er takmörkuð, sem getur verið ein ástæða pess að foreldra skortir traust á íslensku skólakerfi. 
Í nokkrum rannsóknum (Hamilton, 2003; McBrien, 2011) er bent á að ein meginorsök fyrir takmarkaðri pátttöku foreldra í skólastarfi séu tungumálahindranir sem birtast meðal annars í viðhorfum kennara sem efuðust um að foreldrarnir skildu eða vissu hvernig æetti að nálgast tölvupóst sem foreldrum var sendur frá skólanum. Tölvupóstur er hins vegar dæmi um einhliða samskiptaleið og ef foreldrarnir eiga í tungumálaerfiðleikum er mjög líklegt að peir missi af tækifærum til að spyrjast fyrir um skólann og frammistöðu barna sinna (Hermína Gunnpórsdóttir o.fl., 2018).

Pátttaka getur haft ólík birtingarform en samkvæmt Hamilton (2003) fer pað eftir pví um hvaða markhóp er að ræða hvernig hún er skilgreind og pað er mikilvægt að skólar geri ekki sömu væntingar um pátttöku til allra foreldra í skólanum, óháð pörfum peirra. Pess vegna purfa skólar að vera menningarlega næmir í viðleitni sinni til að fá foreldra til pátttöku. Skólarnir sem koma við sögu í pessari rannsókn virðast ekki vinna út frá menningarlegum páttum og rýna pannig í samskipti og pátttöku. Einn kennari ræddi opinskátt um stöðu sína við að eiga samskipti við sýrlenska foreldra vegna menningarlegra árekstra. Hún gerði ráð fyrir pví að einn feðranna myndi ekki hlusta á hana par sem hún er kona og par af leiðandi lagði hún sig ekki frekar fram við að auka samskipti. Að grípa til gagnrýninnar fjölmenningarhyggju gæti hjálpað við að leysa slíka stöðu par sem sú nálgun felur í sér að kennarar fá pjálfun í að iðka sjálfsskoðun og koma auga á eigin hlutdrægni (May, 2009). Í rannsókn Hermínu Gunnpórsdóttir o.fl. (2018) er bent á að brestur í samskiptum tengist gjarnan skorti á pjálfun kennara í hvernig eigi að kenna og vinna með nemendum sem eru innflytjendur og með annan menningarlegan bakgrunn en innfæddir nemendur. Баð má leiða að pví líkum að pað gagnist kennurum að fræðast um væntingar foreldranna til menntunar barna sinna, móðurmál peirra, gildi og viðmið, og hvernig börnum var kennt 1 heimalandi peirra. Í pessari rannsókn gáfu flestir kennararnir til kynna að peir fengju ekki næga pjálfun í að takast á við kennslu nemenda sem eru flóttamenn og að peir vildu læra meira um menninguna og tungumálið. McGee Banks (2010) hefur lagt áherslu á pá staðreynd аð kennarar purfi að nálgast foreldrana að fyrra bragði í stað pess að bíða eftir að peir taki pátt. Jafnvel pó kennararnir í pessari rannsókn hafi sýnt af sér vinalegt og pægilegt viðmót gagnvart nemendum og foreldrum sýna niðurstöðurnar að peir hvöttu foreldrana ekki sérstaklega til að taka meiri pátt en nauðsynlegt var.

\section{Niðurstaða og ábendingar}

Fjölmenningarleg hugmyndafræði er talin áhrifarík nálgun til að koma á árangursríku sampættingarferli. Skólar eru kjörinn staður til að vinna með fjölmenningarlega menntun en hún snýst ekki eingöngu um námsefni og námskrá, heldur líka um víðtækara markmið um umbætur í skólum sem miða að öllum og öllu innan skólakerfisins (Banks, 2009). Íslenskir skólar eiga enn nokkuð í land með að vinna að og innleiða fjölmenningarlega menntun. Áherslur skóla purfa að vera skýrar um hvernig eigi að koma á fjölmenningarlegri menntun og hvernig eigi að vinna með nemendum og fjölskyldum með mismunandi menningarlegan bakgrunn. Óaðskiljanlegur hluti fjölmenningarlegrar menntunar er pátttaka foreldra, að koma á skýrum samskiptum heimilis og skóla og að undirbúa kennara til að takast á við fjölbreytileika.

Eins og sést í pessari rannsókn vantar talsvert upp á að pessi atriði séu markvisst til staðar. Til að auka samskipti heimilis og skóla og auka pátttöku foreldra er mikilvægt að kennarar og starfsmenn skólans séu pjálfaðir í hvernig eigi að beita fjölmenningarlegri menntun, fái upplýsingar um menningu og tungumál fjölskyldnanna, og pjálfist í að vinna með ólíkar birtingarmyndir mismunandi menningar. Kennarar purfa að virkja foreldra til pátttöku og veita peim víðtækar upplýsingar um skólakerfið og menntun barna peirra. Рað er jákvætt og ánægjulegt að sjá að bæði nemendur og foreldrar bera kennurum vel söguna í viðleitni peirra til að koma til móts við nemendur á jafnréttisgrunni. Sjónarmið og sýn kennara er að nemandinn njóti og efli styrkleika sína og fái tækifæri til að vera skapandi, og að áhugi á námi komi innan frá. 
Að endingu er mikilvægt að taka viðtöl við fjölskyldurnar aftur eftir nokkur ár, til að skilja betur aðlögunarferli peirra. Til að skilja aðlögunarferli flóttamannanemenda innan skólakerfisins parf að gera frekari rannsóknir, svo sem tengdar félagslífi peirra og máltöku. Auk pess eru sambærilegar rannsóknir með flóttamannafjölskyldum sem búa á mismunandi stöðum á Íslandi nauðsynlegar til að auka skilning á menntun flóttamanna á Íslandi í heild sinni og eftir landshlutum ásamt ólíkum aðstæðum.

\section{Syrian students in Icelandic compulsory schools: The experiences of students, parents and teachers}

In 2016 Iceland, in cooperation with the United Nations High Commissioner for Refugees (UNHCR), received a group of Syrian quota refugees who had been stationed in Lebanese refugee camps. The group included families with school age children. Education is an important aspect of refugees' adaptation process, as it is a key venue of mutual learning, both for the inhabitants of the receiving country and its prospective residents (Hannah, 2007). The purpose of this research is to improve education policies and practices relating to refugees by highlighting refugee students' voices, as well as those of their parents and teachers. The main objectives involve assessing the experiences of the Syrian students and their parents and teachers at compulsory school level, by focusing on their personal perspectives, aspirations and challenges.

By investigating the experiences and impressions of students, parents, teachers and others who participate in the study process, valuable information may be gathered for the purpose of facilitating this group's adaptation and learning.

This research was conducted with the participation of families residing outside the capital, in areas where only a small number of residents are of Arab origin.

Refugees often arrive in groups in their host country and as a result become obvious minority groups, especially if they exhibit characteristics from their home country such as language and culture (Anderson, 2003).

Various theories outline the adjustment process of refugees when moving to their host country, one of those being Berry's (2005) theory of acculturation where he defines four adaptation approaches linked to two main premises; on the one hand, how strongly people prioritise the preservation of their cultural customs and self-image and, on the other, their readiness to participate in the larger community together with other social groups.

Regarding the refugees' (the minority group), adjustment is considered to occur when individuals no longer emphasise the conservation of their cultural self-image but prefer daily relationships within the host country's cultural environment. Separation, however, takes place when individuals hold on to their own customs and traditions, avoiding participation in another culture (Berry, 2005). In the latter instance the person concerned does not adopt the dominant language or values of the host country, but preserves his/her own cultural traits (Anderson, 2003). Integration occurs when there is a wish to preserve own culture and at the same time participate in everyday contacts with other groups. Integration is regarded as the option that carries the strongest positive results. The least desirable outcome is marginalisation when there is but little interest in own cultural customs (for various reasons, for example "enforced cultural loss") as well as reluctance to socialise with other groups (for reasons such as exclusion and discrimination) (Berry, 2005). 
Recent research by Eva Harðardóttir and Berglind Rós Magnúsdóttir (2018) on mainstream trends and policies regarding young refugees in Icelandic primary and secondary schools indicated that the concept of adaptation focuses, first and foremost, on measures to help refugees adapt to Icelandic conditions and society, without assuming any mutual adjustment of Icelandic society. This focus is in the spirit of assimilation. The conclusions of their research also suggest that the comprehension of diversity is of a somewhat rigid and uniform nature, defining and separating groups on the basis of religion, culture or nationality. This distinction between separate cultures was found, for example, in research interviews with teachers.

Three Syrian families, consisting of three fathers, three mothers and six children, volunteered to participate on the basis of the following criteria: (1) are classified as quota refugees, (2) live outside the capital area, and (3) have at least one child registered in an Icelandic primary school. Semi-structured interviews (Fife, 2005) were carried out with parents, students and five teachers - four female and one male in the spring of 2018. Individual interviews were conducted with parents and teachers and group interviews with students. All interviews lasted 30-60 minutes and were sound-recorded upon agreement by participants. After each interview the recording was transcribed verbatim in English. Interviews in Arabic with parents and students were translated into English. The interviews were construed in accordance with the principles of thematic analysis and the data processed by means of descriptive content analysis (Vaismoradi et al., 2013).

The results indicate that cultural values have affected the education process and the relationship between home and school. As a consequence parents did not fully trust the Icelandic schools their children attended. It was also found that teachers lacked the appropriate support and training to get to grips with this particular group of students. Nevertheless, the students themselves state that they are happy at school and have a positive relationship with their teachers.

Key words: Icelandic compulsory schools, education, multicultural education, refugees

\section{Um höfundana}

Hermína Gunnpórsdóttir (hermina@unak.is) er prófessor við Háskólann á Akureyr i. Hún lauk doktorsprófi frá Háskóla Íslands 2014 og hefur starfad við leik-, grunnog framhaldsskóla. Helstu viðfangsefni hennar í kennslu og rannsóknum tengjast $\mathrm{f}$ élagslegu réttlæti í menntun, skóla og námi án aðgreiningar, fjölmenningu og me nntun, fötlunarfræði, menntastefnu og framkvæmd. Hermína er virk í norrænum og evrópskum samstarfsnetum um menntun án aðgreiningar, QUINT, norrænu öndvegissetri um gæði náms og ýmsum rannsóknarhópum á Îslandi og erlendis.

Kheirie El Hariri (kheirie.elhariri@gmail.com) útskrifaðist vorið 2019 með MApróf í félagsvísindum frá Háskólanum á Akureyri. Hún hefur kennt sýrlenskum flóttabörnum á grunnskólaaldri í Líbanon og leiðbeint kennurum við að takast á við kennslu nemenda með erfiðan og flókinn bakgrunn, t.d. nemendur með stöðu flóttafólks og lága efnahags- og félagslega stöðu.

Markus Meckl (markus@unak.is) er með doktorspróf frá Tækniháskólanum í Berlín par sem hann stundaði nám við Miðstöð rannsókna um and-semítisma. Síðan 2004 hefur hann starfað við Háskólann á Akureyri og gegnir par starfi prófessors í fjölmiðlafræði. Í rannsóknum sínum seinustu árin hefur hann einkum einblínt á 
innflytjendamál á Norðurlandi og birt fjölda greina um efnið. Hann tekur virkan pátt í verkefnum sem snúa að innflytjenda- og aðlögunarmálum á Norðurlöndunum og í Eystrasaltslöndunum og byggir par m.a. á víðtækri reynslu sinni af rannsóknasamstarfi með Háskóla Lettlands í Riga og Lettnesku menningarakademíunni.

\section{About the authors}

Hermína Gunnpórsdóttir (hermina@unak.is) is a professor at the University of Akureyri. She holds a PhD from the University of Iceland (2014). She has worked at kindergarten, primary and secondary schools. Her teaching and research interest is related to social justice in education, inclusive school and education, multiculturalism and education, disability studies, educational policy and practice. She is an active member of the Nordic and European Network on Inclusive Education, QUINT - the Nordic Centre of Excellence and numerous research groups in Iceland and abroad.

Kheirie El Hariri (kheirie.elhariri@gmail.com) graduated in spring 2019 from University of Akureyri with an MA in Social Sciences. She has experience in teaching Syrian refugee students at elementary level in Lebanon, and in mentoring teachers dealing with students coming from difficult backgrounds, such as refugees or students from low socio-economic classes.

Markus Meckl (markus@unak.is) holds a Ph.D. from Berlin Technical University where he studied at the Center for Research on Anti-Semitism. Since 2004, he has been working at the University of Akureyri where he is a professor in media studies. In recent years, one of his research interests has focused on immigration issues in the North of Iceland from which a series of articles has been published. Drawing on a broad range of experience, including teaching at the University of Latvia and the Latvian Academy of Culture, he is involved in immigration and integration-related projects in the Nordic and Baltic countries.

\section{Heimildir}

Anderson, A. (2003). Issues of migration. Í R. Hamilton og D. Moore (ritstjórar), Educational interventions for refugee children: Theoretical perspectives and implementing best practices (bls. 64-82). New York, NY: Routledge.

Anh-Dao Tran og Samúel Lefever. (2018). Icelandic-born students of immigrant background: How are they faring in compulsory schools? Í Hanna Ragnarsdóttir og Samúel Lefever (ritstjórar), Icelandic studies on diversity and social justice in education (bls. 39-59). Newcastle upon Tyne: Cambridge Scholars Publishing.

Banks, J.A. (2009). Multicultural education: Dimensions and paradigms. Í J.A. Banks (ritstjóri), The Routledge international companion to multicultural education (bls. 9-32). New York, NY: Routledge.

Banks, J. A. (2013). Multicultural education: Characteristics and goals. Í J. A. Banks og C. A. McGee Banks (ritstjórar), Multicultural education: Issues and perspectives (8. útgáfa), (bls. 3-23). Hoboken, NJ:Wiley.

Berry, W. J. (2005). Acculturation: Living successfully in two cultures. International Journal of Intercultural Relations, 29(6), 697-712.

Block, K., Cross, S., Riggs, E. og Gibbs, L. (2014). Supporting schools to create an inclusive environment for refugee students. International Journal of Inclusive Education, 18(12), 1337-1355. doi:10.1080/1360311 6.2014 .899636

Braun,V. og Clarke, V. (2006). Using thematic analysis in psychology. Qualitative Research in Psychology, 3(2), 77-101. doi:10.1191/1478088706qp063oa

Castles, S. (2009). World population movements, diversity, and education. Í J.A. Banks (ritstjóri), The Routledge international companion to multicultural education (bls. 49-61). New York, NY: Routledge.

Creswell, J.W. (2012). Educational research: Planning, conducting and evaluating quantitative and qualitative research (4. útgáfa). Boston: Pearson. 
Esterberg, K. (2002). Qualitative methods in social sciences. New York: McGraw Hill.

Eva Harðardóttir og Berglind Rós Magnúsdóttir. (2018). „Að preifa sig áfram í myrkrinu“: Ríkjandi stefnur og straumar um ungt flóttafólk í íslensku grunn- og framhaldsskólakerfi. Stjórnmál og stjórnsýsla, 14(3), 183-204. doi:10.13177/irpa.a.2018.14.3.2

Ficarra, J. (2017). Comparative international approaches to better understanding and supporting refugee learners. Issues in Teacher Education, 26(1), 73-84.

Fife, W. (2005). Doing fieldwork: Ethnographic methods for research in developing countries and beyond. New York, NY: Palgrave Macmillan.

Gay, G. (2010). Culturally responsive teaching: Theory, research, and practice (2. útgáfa). New York, NY: Teachers College Press.

Hamilton, R. (2003). Schools, teachers and the education of refugee children. Í R. Hamilton og D. Moore (ritstjórar), Educational interventions for refugee children: Theoretical perspectives and implementing best practices (bls. 83-96). New York, NY: Routledge.

Hanna Ragnarsdóttir (ritstjóri). (2015). Learning spaces for inclusion and social justice: Success stories from immigrant students and school communities in four Nordic countries. Report on main findings from Finland, Iceland, Norway and Sweden. Sótt af http://1sp2015.hi.is/final_report

Hanna Ragnarsdóttir og Susan Rafik Hama. (2018). Refugee children in Icelandic schools: Experiences of families and schools. Í Hanna Ragnarsdóttir og Samuel Lefever (ritstjórar), Icelandic studies on diversity and social justice in education [Book series: Nordic studies on diversity in education] (bls. 82-104). Cambridge: Cambridge Scholars Publishing.

Hannah, J. (2007). The role of education and training in the empowerment and inclusion of migrants and refugees. Education and Society, 25(1), 5-23. doi:10.7459/es/25.1.02

Helga Jónsdóttir. (2013).Viðtöl í eigindlegum og megindlegum rannsóknum. Í Sigríður Halldórsdóttir (ritstjóri), Handbók i aðferðafraði rannsókna (bls. 137-153). Akureyri: Háskólinn á Akureyri.

Hermína Gunnpórsdóttir, Barillé, S. og Meckl, M. (2018). The education of students with immigrant background in Iceland: Parents' and teachers' voices. Scandinavian Journal of Educational Research, 63(4), 605-616. doi:10.1080/00313831.2017.1415966

Hofstede, G. (2011). Dimensionalizing cultures: Hofstede model in context. Online Readings in Psychology and Culture, 2(1). doi:10.9707/2307-0919.1014

Hofstede, G., Hofstede, G. J. og Minkov, M. (2010). Cultures and organizations: Software for the mind (3. útgáfa). New York, NY: McGraw-Hill.

Hofstede Insights. (e.d.). Compare countries. Sótt af https://www.hofstede-insights.com/product/compare-countries/

Lerner, B. A. (2012). The educational resettlement of refugee children: Examining several theoretical approaches. Multicultural Education, 20(1), 9-14.

May, S. (2009). Critical multiculturalism and education. Í J. A. Banks (ritstjóri), The Routledge international companion to multicultural education (bls. 33-48). New York og London: Routledge.

McBrien, J. L. (2005). Educational needs and barriers for refugee students in the United States: A review of the literature. Review of Educational Research, 75(3), 329-364. doi:10.3102/00346543075003329

McBrien, J. L. (2011). The importance of context:Vietnamese, Somali, and Iranian refugee mothers discuss their resettled lives and involvement in their children's schools. Compare: A Journal of Comparative and International Education, 41(1), 75-90. doi:10.1080/03057925.2010.523168

McGee Banks,A. C. (2010). Communities, families and educators working together for school improvement. Í J.A. Banks og C.A. McGee Banks (ritstjórar), Multicultural education: Issues and perspectives (bls. 417-438). Hoboken, NJ:Wiley.

Mennta- og menningarmálaráđuneyti. (2013). Aðalnámskrá grunnskóla:Almennur hluti 2011: Greinasvið 2013. Sótt af https://www.stjornarradid.is/default.aspx?PageID=47080c0c-c37e-11e6-9409-005056bc4d74\#Tab0

Nieto, S. (2009). Language, culture, and teaching: Critical perspectives (2. útgáfa). New York, NY og London: Routledge. 
Nieto, S. og Bode, P. (2010). School reform and student learning: A multicultural perspective. Í J. A. Banks og C. A. McGee Banks (ritstjórar), Multicultural education: Issues and perspectives (bls. 395-416). Hoboken, NJ:Wiley.

Sheikh, M. og Anderson, R. J. (2018). Acculturation pattern and education of refugees and asylum seekers: A systematic literature review. Learning and Individual Differences, 67(1), 22-32. doi:10.1016/j.lindif.2018.07.003

Taylor, S. og Sidhu, K. R. (2012). Supporting refugee students in schools: What constitutes inclusive education? International Journal of Inclusive Education, 16(1), 39-56. doi:10.1080/13603110903560085

Thomas, R. L. (2016). The right to quality education for refugee children through social inclusion. Journal of Human Rights and Social Work, 1(1), 193-201. doi:10.1007/s41134-016-0022-z

Vaismoradi, M., Turunen, H. og Bondas, T. (2013). Content analysis and thematic analysis: Implications for conducting a qualitative descriptive study. Nursing and Health Sciences, 15(1), 398-405. doi:10.1111/nhs.12048

Hermína Gunnpórsdóttir, Kheirie El Hariri og Markus Meckl. (2020).

Sýrlenskir nemendur í íslenskum grunnskólum: Upplifun nemenda, foreldra og kennara

Netla - Veftímarit um uppeldi og menntun. Menntavísindasvið Háskóla Íslands.

Sótt af http://netla.hi.is/greinar/2020/ryn/08

DOI: https://doi.org/10.24270/netla.2020.8 